\title{
TRENDS OF HOUSING CONSTRUCTION DEVELOPMENT IN UKRAINE: RETROSPECTIVE AND CONTEMPORARY SITUATION
}

\author{
Natalya BIBIK ${ }^{1}$, Natalia DRIL ${ }^{2}$ \\ ${ }^{1,2}$ O. M. Beketov National University of Urban Economy in Khakriv, 61002, Kharkiv, \\ Marshala Bazhanova Street, 17, Ukraine \\ Corresponding author e-mail: nvbibik@gmail.com
}

\begin{abstract}
The construction industry is one of the main components of the national economy of Ukraine as well as many countries worldwide. The volume and level of construction, especially housing, considerably influence further development of all other sectors of economy, and guarantee continuous growth of economic potential and national income. The aim of the research is to analyze the trends of construction development, its historical background and current situation in Ukraine. Literature analysis methods, statistical data processing, historical and logical access methods have been used in the research. The article provides historical overview of housing construction development in Ukraine, current challenges in the industry and solutions to solve them.
\end{abstract}

Keywords: Coefficient of housing update, compact housing, dwelling area per person, housing construction, housing market

\section{INTRODUCTION}

The process of economic reforms in Ukraine put forward a number of challenges that are crucial for the country. Housing construction one of the vital problems; it has a substantial impact on the economic and social situation of the regions and country as a whole (Thalmann, 1999). The social impact of housing development lies in solving housing problems and improving employment while providing economic effect focused on increasing production volumes of related industries (construction materials, machinery, metallurgy, wood processing and chemical industries, etc.) (Bramley, 2012).

The aim of the research is to analyze the trends of construction development, its historical background and current situation in Ukraine. Literature analysis methods, statistical data processing, historical and logical access methods have been used in the research.

Considering current economic situation in Ukraine, which could be characterized as a mix of financial, economic, banking and political crises, it is important to stimulate the dominant industries and sectors of the national economy, including construction industry. The functioning of the construction industry provides significant amounts of revenue from the initial sale, especially in the sector of housing real estate. Thus it is crucial to analyze the current state of housing construction, define main problems and propose directions for their resolution. 


\section{HISTORICAL RETROSPECTIVE OF HOUSING REAL ESTATE DEVELOPMENT IN UKRAINE}

In order to understand the current situation in the construction industry in Ukraine it is important to determine the main steps of real estate development in the past.

The objective conditions of formation of the domestic housing market were formed in the early 1990s in XX century after the declaration of Ukrainian independence. By that time, in terms of centrally planned economic system, provision of housing was based on state distribution and not on market principles.

The state performed multiple functions in the residential sector. First, it was the major investor in residential construction. Secondly, the state acted as the contractor, the developer in the field of housing and the owner of the main part of the housing stock (Kovtyn, 2014). In addition to state-owned housing in this period there were housing co-operatives and individual housing owners, but they played a secondary role as subjects of property rights to housing. Long-term loans to finance housing construction had a minor role and were provided primarily to individuals and members of housing cooperatives.

Public housing was given to citizens who were registered in a special queue to receive it free of charge. This led to the need to ensure strict regulations limiting residential area and the rules for determining the needs of the population in housing. It was established with the maximum size of the living space that could be provided per one person - 13.65 square meters. As the family was growing, most people had to exchange their housing two or three times to improve living conditions.

Phase I (1991-1996) - the creation and formation of the market. Housing prices in Ukraine were lower than the prices in other European countries. The number and quality of housing proposals were very low. Therefore, the growth of incomes, housing privatization and liberalization of the market led to its the rapid growth. As a result, during 1991-1993 there was a surge in the prices in the secondary market, there was a significant excess of demand over supply. Prices reached their peak in 1993 followed by a definite drop in prices, which stopped starting from 1995.

Phase II (1997 - first half of 1998) - the period of price stability, which was caused by the satisfaction of the customer demand for housing in the previous period. Overall, the number of purchase and sale transactions in the market decreased. The prices were still growing, albeit much slower than in the previous period.

Phase III (second half 1998-2000) - the period of rapid price decline. Particularly strong fall in prices was observed during the second half of 1998 and in 1999. In 1999-2000, inflation rate was two times higher than the growth in the housing prices. Therefore, money which were not invested in real estate, were devalued twice faster. In the following years, this resulted in a significant increase in the activity rate in the housing market, especially in order to protect available income from inflation.

Phase IV (January - August 2001) - the beginning of the gradual rise in prices. In the first eight months of 2001, property prices began to rise slowly, especially in Kyiv, which was caused by the processes in the previous phase. The phase was 
characterized by a rapidly growing primary housing market, expanding infrastructure, and increasing competition among real estate agencies. Banks began to develop mortgage lending, regulations and laws in the field of real estate were improved.

Phase V (September 2001-2007) - sharp and continuous rise in prices. The concern of people about the stability of the US economy and the US dollar resulted in significant capital flow to the real estate market. In 2002-2005, other factors started to operate: economic growth, increase of financial solvency, as well as growth in mortgage lending. At the beginning of 2004, VAT for developers was introduced. Housing prices increased 2.6 times in comparison with 2003.

In 2005, a tax on real estate transactions was a new factor that gave impetus to the growth in the housing prices. The increase in the tax burden significantly influenced the behavior and intentions of market participants and increased the cost of housing. Prices were steadily rising, a reduction in contracts of sale of flats and houses was observed.

Phase VI (2007-2008) - period of price shock and opposition trends in the housing market. There was fierce struggle of opposing trends. On the one hand, the further ("unlimited") growth rates were observed, on the other, there was a trend to reduce them to "complete" collapse. Opposite expectations led to a huge number of analytical information and forecasts with opposite results.

The trend to lower prices in the housing market resulted from low solvency of the buyers; reorientation from mortgages to consumption (purchase of transport vehicles, equipment); some outflow of speculative funds, including credits; reorientation of investment in commercial real estate and land resulting in lower pressure on the market; psychological component (customer discontent with the constant rise in prices). The trend to raise prices in the housing market resulted from: rising prices for resources and materials for housing; increased risks of changes in land laws by government, land prices; inflation; the lack of other financial instruments to invest surplus funds and private savings; slight growth rate of primarily housing building, which remained at the level of 2006; some financial strength reserve of developers, which attempted to maintain prices. Collapse in prices in the housing market did not happen. The expected growth did not occur either. Prices at the beginning of 2008 reached a certain limit, social and economic situation in the country affected the sharp decline in the number of transactions.

Phase VII (2009) - decline in the volume of activity in the market, there was pent-up demand due to lower incomes, lack of credit resources, decrease in investment attractiveness of real estate, including the speculative motive.

Many buyers, who bought lodgings at the phase of the price peak on credit, got higher loan debt than the real value of the purchased apartment. In this situation, even the sale of such apartment could not solve borrowers' problems and help to return the borrowed money. "Price bubble" in the Ukrainian real estate market did not burst, but only slightly reduced. After decline in real wages, huge price disparity between incomes of the majority of citizens and housing prices did not decrease, and for certain categories of potential buyers even increased. The actual solvency of the population fell by $30 \%$ and that significantly reduced the possibility of the population to save and invest. There was a dramatic collapse in demand and mainly 
for the objects at the phase of construction. In general, the crisis changed the attitudes to property investment, especially to house-buying using mortgage services at considerable interest rates (Omelchyk, 2010).

Phase VIII (2010-2011) - stabilization of hryvnia to USD and EUR, as well as reduction of the rate of the National Bank of Ukraine had a positive effect on recovery of credit policy in 2010. We passed the period of "rock bottom prices" of real estate, construction of objects with high degree of readiness (over 60\%) was completed and new objects with high level of reliability were financed. Transactions involving credit facilities constituted between 5-7\% of the total and the amount of loans reached 10-20 thousand US dollars. It was used to cover the lack of own funds and not for property acquisition. In 2011 banks offered loans in hryvnia in average at $18 \%$ and above, with an initial contribution in the range of 25-50\% usually as a security backing for the objects that were purchased on the secondary market. These changes contributed to enhancement of investment and construction activity and increased putting of housing into operation. Demand increased primarily in the sector of economical lodging, respectively, the prices in this segment were rising.

Phase IX (2012 - August 2013) - the number of construction sites put into operation and the level of consumer activity were increasing. The characteristic feature of this period was developers' reorientation to meet the needs of the customers, which involved reducing of the total area of an apartment, constructing one-bedroom apartments of 35-56 square meters instead of 60 square meters and two-bedroom apartments of 68-82 square meters instead of 90 square meters, which were built earlier. The demand in the primary real estate market increased because the price of new apartments became similar to the price of such apartments in the secondary market. Thus, notaries of Ukraine certified almost 266,000 share purchase agreements in 2012. The specified number of agreements is higher by almost $4.5 \%$ than in 2011 and by $18 \%$ than in 2010 . As can be seen from the above, the market was recovering gradually. The Law of Ukraine "On amendments to some legislative acts of Ukraine on state registration of rights to real property of land and property rights to real estate" was passed and entered in to force on 1 January 2013. The new procedure for registration of real estate significantly reduced the package of documents for registration of new buildings, simplified the system of registration of lease, mortgage, but its implementation slightly restrained execution of agreements of sale and purchase in early 2013 (Karapetyan \& Kvasovskyi, 2013).

Phase X (September 2013 - present time) - stagnation of the real estate market. This phase is characterized by the new legislative changes that significantly affected the real estate market, especially restrictions on cash transactions to the amount of 150 thousand UAH that were introduced by the National Bank of Ukraine from 1 September, 2013, the assessment process for tax and accrual, as well as payment of other compulsory payments, which are imposed according to the prospective legislation from 1 November, 2013. Limiting of cash transactions to the amount of 150 thousand UAH caused decrease of the number of transactions in the secondary real estate market by $50-60 \%$ due to additional financial burden ( 1 to $3 \%$ of the housing cost) and people's unwillingness to declare their income in 
this way. In addition, new rules with regard to real estate evaluation led to additional costs amounting to 500 USD at an average. The main negative aspects that influenced the stagnation in the real estate market include reduced income of the citizens and small and medium-sized enterprises, expectations of hryvnia evaluation against the dollar, degradation of political and economic situation in the country. According to expert evaluations, the proportion of financially reliable people with average income - potential buyers of the real estate market - decreased from $10 \%$ to $3-5 \%$. At the same time, significant reduction in lending caused financial difficulties for real estate developers, some of them even stopped construction until the political situation in the country stabilizes. The devaluation of the currency, which happened on 7 February 2014 due to transition to a floating exchange rate of hryvnia against the USD, put a strain on investors in the real estate market. In our opinion, exit of the real estate market from the state of stagnation is possible after resolving of political crisis in the country and consequent stabilization of exchange rate, as well as gradual recovery of lending. Taking into account the importance of such criterion as price for the current study, it is necessary to illustrate graphically the phases of development of the Ukrainian real estate market.

\section{CURRENT CHALLENGES OF HOUSING CONSTRUCTION IN UKRAINE}

The current situation in the construction industry in Ukraine shows unsatisfactory dynamics of housing construction due to the housing deterioration and slow growth of commissioned housing. As a result, the growth rate of housing construction and housing renewal is very low (Sych, 2015). The coefficient of housing renewal is calculated as the share of commissioned housing in the total housing area (percentage):

$$
K=\frac{V_{n}}{V_{z}} \times 100 \%,
$$

where $K$ - coefficient of housing renewal in \%;

$V_{n}$ - area of commissioned housing in the present year;

$V_{z}$ - housing area at the end of the year.

The coefficient allows comparing the scale of housing construction and housing. The calculation of the coefficient is presented in Table 1. 
Table 1. Coefficient of housing renewal, Ukraine

\begin{tabular}{|c|c|c|c|c|}
\hline Year & $\begin{array}{c}\text { Total area, } \\
\text { mln.m }\end{array}$ & $\begin{array}{l}\text { Commissioned } \\
\text { housing, mln.m }\end{array}$ & $\begin{array}{l}\text { Coefficient of } \\
\text { housing } \\
\text { renewal, \% }\end{array}$ & $\begin{array}{c}\text { The period of full } \\
\text { renewal of housing, } \\
\text { years }\end{array}$ \\
\hline 1990 & 922.10 & 17.45 & 1.89 & 52.84 \\
\hline 1995 & 978.30 & 8.66 & 0.89 & 112.97 \\
\hline 2000 & 1015.00 & 5.56 & 0.55 & 182.55 \\
\hline 2001 & 1026.10 & 5.94 & 0.58 & 172.74 \\
\hline 2002 & 1031.70 & 6.07 & 0.59 & 169.97 \\
\hline 2003 & 1035.70 & 6.43 & 0.62 & 161.07 \\
\hline 2004 & 1040.00 & 7.57 & 0.73 & 137.38 \\
\hline 2005 & 1046.40 & 7.82 & 0.75 & 133.81 \\
\hline 2006 & 1049.20 & 8.63 & 0.82 & 121.58 \\
\hline 2007 & 1057.60 & 10.24 & 0.97 & 103.28 \\
\hline 2008 & 1066.64 & 10.50 & 0.98 & 101.58 \\
\hline 2009 & 1072.24 & 6.40 & 0.60 & 167.54 \\
\hline 2010 & 1079.54 & 9.34 & 0.87 & 115.58 \\
\hline 2011 & 1086.04 & 9.41 & 0.87 & 115.41 \\
\hline 2012 & 1094.24 & 10.75 & 0.98 & 101.79 \\
\hline 2013 & 1096.64 & 11.22 & 1.02 & 97.74 \\
\hline 2014 & 966.14 & 9.74 & 1.01 & 99.19 \\
\hline 2015 & 973.84 & 11.04 & 1.13 & 88.21 \\
\hline 2016 & 982.88 & 9.37 & 0.95 & 104.90 \\
\hline
\end{tabular}

Source: State Statistics Service of Ukraine, 2017

According to the data in Table 1, in 1990 the coefficient of housing renewal was $1.9 \%$. Thus, it would take 53 years to fully update the housing existing at that time while maintaining the volume of construction. However, in subsequent years, there was a decline in the renewal of housing stock two or more times, and only in 2013-2015 there was a certain improvement. Thus, according to the official statistics in Ukraine 52.8 percent of people in 2016 lived in overcrowded apartments in the houses, 53\% of which were built in the 1970s and 80s (State Statistics Service of Ukraine, 2017). Partly it is caused by the conflict on the east and south of Ukraine.

Moreover, the crisis of the recent years observed in Ukraine reduced citizens' purchasing power and moved residential property from the products providing primary physiological needs to elusive multi-facility accumulation for the average middle-income Ukrainian (Zapototskyy, Zapototska, \& Gorin, 2014).

Considering the average salary in Ukraine (as of February 1, 2017 6,209 hryvnia, or about $\$ 230$ ), housing cost in relation to the salary of the average Ukrainian has been excessively high. As of January 1, 2017, the market value of $1 \mathrm{~m}^{2}$ of economy class housing in new buildings on average would cost 15,000 hryvnia (\$560). To purchase a two-bedroom apartment with the total area 
of $65 \mathrm{~m}^{2}$, worth 975,000 hryvnia, or $\$ 36,000$, the average household of two people in Ukraine must work for almost 7 years. However, this calculation does not include the monthly household expenditure. Assuming that households spend half of their income and save the remainder to accumulate for housing, the housing affordability index will be 14 years, thus making it almost impossible for an average resident to buy an apartment in the nearest future. The current financial and economic crisis in Ukraine and unstable bank system - loan or any other form of financial support is hardly available for most citizens in Ukraine - force construction companies search for a new ways to meet the needs of the customers and datisfy the demand (Dril \& Olhovskaya, 2016).

An indicator of total floor area per person is the most generalized indicator used to evaluate existing potential of housing economy and the actual level of availability of housing (Galster, 1987).

The average dwelling area per person in Ukraine in 2016 was $24.2 \mathrm{~m}^{2}$ (State Statistics Service of Ukraine, 2017). Figure 1 shows the relatively small growth in the number of dwelling area per person in the past ten years in Ukraine. Moreover, the analysis of the average size of dwelling by tenure status in EU shows that with the lowest level in Romania of $44.6 \mathrm{~m}^{2}$ (Table 2), the dwelling area per person in Ukraine is the lowest.

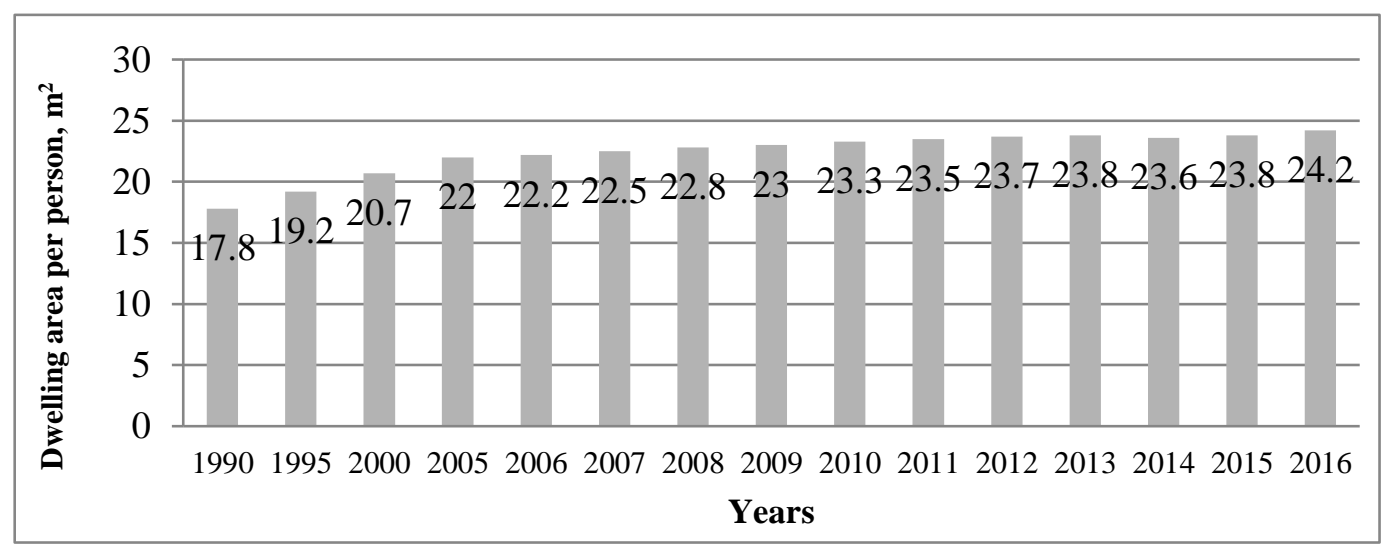

Fig. 1. Dwelling area per person in Ukraine between 1990-2016, $\mathrm{m}^{2}$. Source: State Statistics Service of Ukraine

Relatively low dwelling area per person in Ukraine to some extent is caused by low level of housing construction. In 2000-2016, from 5.5 to 11 million $\mathrm{m}^{2}$ were built in Ukraine (Table 1), an average of 8.6 million $\mathrm{m}^{2}$ of housing annually.

The lowest rate of housing construction was recorded in 2000, when only 5.5 million $\mathrm{m}^{2}$ of housing were built. Since 2001, Ukraine has a tendency to gradually increase the volume of housing construction.

Restoration of housing construction in the 2000s was observed purely in the primary market, financed on the commercial basis. The property was built attracting funds from private investors (Bibik, 2014). 
Table 2. Average size of dwelling by tenure status, $\mathrm{m}^{2}, 2012$

\begin{tabular}{|c|c|c|c|c|c|}
\hline & \multirow[b]{2}{*}{$\begin{array}{c}\text { Total } \\
\text { population }\end{array}$} & \multicolumn{2}{|c|}{ Owner } & \multicolumn{2}{|c|}{ Tenant } \\
\hline & & $\begin{array}{c}\text { without } \\
\text { mortgage }\end{array}$ & $\begin{array}{c}\text { with } \\
\text { mortgage }\end{array}$ & market price & $\begin{array}{c}\text { reduced } \\
\text { price or free }\end{array}$ \\
\hline EU-28 (') & 95.9 & 96.8 & 119.7 & 74.5 & 78.7 \\
\hline EA-19 (') & 95.9 & 105.5 & 115.8 & 71.2 & 77.2 \\
\hline Belgium & 124.3 & 139.0 & 145.5 & 85.7 & 91.0 \\
\hline Bulgaria & 73.0 & 75.0 & 76.3 & 53.7 & 60.9 \\
\hline Czech Republic & 78.0 & 80.7 & 92.9 & 59.1 & 63.1 \\
\hline Denmark & 115.6 & 141.4 & 146.6 & 79.6 & 117.1 \\
\hline Germany & 94.3 & 121.4 & 127.7 & 69.2 & 74.3 \\
\hline Estonia & 66.7 & 68.0 & 83.4 & 44.3 & 53.3 \\
\hline Ireland & 80.8 & 83.0 & 98.9 & 63.7 & 58.4 \\
\hline Greece & 88.6 & 93.4 & 100.3 & 70.6 & 79.1 \\
\hline Spain & 99.1 & 103.3 & 101.4 & 81.0 & 92.8 \\
\hline France & 93.7 & 110.1 & 108.9 & 66.7 & 71.3 \\
\hline Croatia & 81.6 & 82.7 & 87.6 & 57.7 & 72.8 \\
\hline Italy & 93.6 & 99.6 & 98.6 & 73.9 & 82.0 \\
\hline Cyprus & 141.4 & 156.5 & 177.6 & 91.9 & 112.3 \\
\hline Latvia & 62.5 & 64.3 & 85.1 & 44.7 & 48.6 \\
\hline Lithuania & 63.2 & 64.4 & 70.9 & 42.5 & 47.6 \\
\hline Luxembourg & 131.1 & 156.4 & 147.6 & 83.2 & 106.4 \\
\hline Hungary & 75.6 & 77.9 & 81.2 & 49.8 & 56.2 \\
\hline Malta $\left({ }^{2}\right)$ & $:$ & $:$ & $\vdots$ & $:$ & 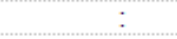 \\
\hline Netherlands & 106.7 & 133.1 & 127.8 & 78.0 & 113.2 \\
\hline Austria & 99.7 & 125.3 & 130.2 & 66.6 & 81.0 \\
\hline Poland & 75.2 & 80.4 & 88.1 & 45.7 & 52.5 \\
\hline Portugal & 106.4 & 110.5 & 123.5 & 77.6 & 82.8 \\
\hline Romania & 44.6 & 44.9 & 44.7 & 32.4 & 34.5 \\
\hline Slovenia & 80.3 & 86.0 & 93.6 & 47.6 & 66.1 \\
\hline Slovakia & 87.4 & 89.2 & 95.4 & 63.1 & 76.5 \\
\hline Finland & 88.6 & 99.4 & 109.8 & 54.3 & 55.6 \\
\hline Sweden & 103.3 & 105.1 & 125.3 & 69.7 & 131.4 \\
\hline United Kingdom $\left({ }^{2}\right)$ & : & : & : & : & : \\
\hline Iceland & 130.4 & 150.8 & 144.7 & 88.2 & 85.9 \\
\hline Norway & 123.2 & 126.7 & 140.5 & 67.8 & 78.9 \\
\hline Switzerland & 117.1 & 140.0 & 152.9 & 92.0 & 96.6 \\
\hline
\end{tabular}

Source: (Eurostat, 2017)

In 2006-2012, there was a tendency to increase the average size of apartments (Table 3) in new buildings, due to the desire of developers to reduce the capital intensity of construction and thus increase their profits.

The average size of new apartments in urban areas varied from $90 \mathrm{~m}^{2}$ to $100 \mathrm{~m}^{2}$. In 2010 it reached $117.9 \mathrm{~m}^{2}$, although afterwards this number started to decrease to $80.2 \mathrm{~m}^{2}$ in 2016. In general, the current situation with housing real estate in Ukraine, considering overcrowded apartments in the houses, requires raising commissioned housing and in the meantime, taking into account the current financial and economic crisis in Ukraine, reduction of apartment size. The data in Table 3 shows decline of average size of apartments as a result of situation in the market of housing construction. Hence, further development of housing real estate will be possible only through additional revision by the construction companies of apartment size 
toward their reduction, which would sharply reduce the cost of the finished product (Fingleton, 2008).

Table 3. The average size of apartments built, $\mathrm{m}^{2 *}$

\begin{tabular}{|c|r|r|r|r|r|}
\hline \multirow{2}{*}{ Year } & $\begin{array}{c}\text { The } \\
\text { average } \\
\text { size }\end{array}$ & $\begin{array}{c}\text { One room } \\
\text { apartments }\end{array}$ & $\begin{array}{c}\text { Two-room } \\
\text { apartments }\end{array}$ & $\begin{array}{c}\text { Three-room } \\
\text { apartments }\end{array}$ & $\begin{array}{c}\text { Four and } \\
\text { more room } \\
\text { apartments }\end{array}$ \\
\hline 2003 & 98.9 & 46.4 & 63.8 & 90.3 & 130.6 \\
\hline 2004 & 104.6 & 43.7 & 65.4 & 93.3 & 132.5 \\
\hline 2005 & 101.0 & 47.6 & 67.2 & 95.0 & 136.9 \\
\hline 2006 & 102.8 & 50.0 & 69.3 & 98.0 & 144.7 \\
\hline 2007 & 105.9 & 51.5 & 71.4 & 100.3 & 150.5 \\
\hline 2008 & 109.1 & 51.0 & 71.8 & 103.9 & 159.3 \\
\hline 2009 & 96.1 & 52.3 & 73.3 & 103.1 & 170.7 \\
\hline 2010 & 117.9 & 51.3 & 74.6 & 111.5 & 168.7 \\
\hline 2011 & 110.0 & 49.0 & 74.1 & 111.2 & 174.4 \\
\hline 2012 & 113.5 & 48.3 & 73.8 & 110.1 & 166.2 \\
\hline 2013 & 104.6 & 47.1 & 74.0 & 111.7 & 167.2 \\
\hline 2014 & 89.2 & 43.9 & 70.3 & 99.4 & 148.8 \\
\hline 2015 & 87.2 & 42.0 & 67.4 & 97.2 & 145.5 \\
\hline 2016 & 80.2 & 40.0 & 63.2 & 89.4 & 133.8 \\
\hline
\end{tabular}

*Excluding the territory of Crimea and Sevastopol. For the years 2014-2016 excluding Donetsk and Luhansk regions (State Statistics Service of Ukraine, 2017)

The rise of interest in compact flats with reduced size is quite significant; it covers a wide range of dwellings: social housing for students, capsule hotels, private houses, temporary housing for victims of natural disasters or military action (Myhalevych \& Kyrylenko, 2016). The list of options for use may increase over time and the need for such housing is always present. Using the experience of other countries, different ways of developing compact housing in Ukraine can be implemented: use of existing projects involving firms that already have some experience; formation of the Ukrainian product industry considering examples of China and Japan (Cai \& Lu, 2015), or creating a unique product that has inherent properties of Ukrainian architecture.

At present, small-sized housing in many countries is widespread. Different segments of the population for various reasons choose compact housing. Ukraine has a large number of historical examples of small-sized housing, but this experience is mostly disregarded. Introduction of modern compact housing types in the market and availability of social programs for their construction would make it possible to provide housing for certain segments of the population (Oyewole, 2010).

\section{CONCLUSION}

Thus, housing problems of the population and development of the housing market remain among the sharpest and most acute problems in Ukraine due to limited growth opportunities. Housing market is characterized by low volume of work performed, lack of investment, low incomes and limited crediting facilities. 
In addition, the ratio of investment in housing construction, income forecasts and unattractive loans make it impossible to predict the rate of minor housing at least in the short term.

In order to solve the problems associated with lack of housing it is necessary to introduce modern small-sized housing. Its presence in the market of Ukraine already has and will have prospects and will be in large demand, which is confirmed by decrease of average apartment size in Ukraine in 2016. Effective national housing policy can help to solve this problem. Such policy should include measures aimed primarily at stimulating increase in housing construction and, therefore, increase housing supply in the market.

Moreover, commissioning small amount of housing allows developers to maintain high prices for housing and receive profits. Priority should be given to massive quality accommodation at low prices. The next step is to establish support of government through national programs in construction and to support mortgage lending. It is important to simplify and ensure the transparency of public authorities, which make decisions on the issues related to construction of housing in a particular area and foster further development of housing real estate including small-sized one.

\section{REFERENCES}

Bibik, N. (2014). Sučasni pidhodi do viboru optimalnih mistobudivnih rišen, [New Approaches for Selection of Optimal Urban Planning Decisions], Skhid, 6(126), 13-16.

Bramley, G. (2012). Affordability, poverty and housing need: Triangulating measures and standards. Journal of Housing and the Built Environment, 27(2), 133-151. https://doi.org/10.1007/s10901-011-9255-4

Cai W., \& Lu, X. (2015). Housing affordability: Beyond the income and price terms, using China as a case study. Habitat International, 47, 169-175. https://doi.org/10.1016/j.habitatint.2015.01.021

Dril, N., \& Olhovskaya, M. (2016). Investuvannja žitlovogo budivnictva v umovah turbulentnoï ekonomiki [Housing investment in conditions of turbulent economy]. Materiali II mižnarodnö̈ naukovo-praktičnoï internet-konferenciï «Biznes-administruvannja $v$ umovah turbulentnö̈ ekonomiki», (pp. 69-70).

Fingleton, B. (2008). Housing supply, housing demand, and affordability. Urban Studies, 45(8), 1545-1563. https://doi.org/10.1177/0042098008091490

Galster, G. (1987). Identifying the Correlates of Dwelling Satisfaction: An Empirical Critique, Environment and Behavior, 19(5), 539-568. https://doi.org/10.1177/0013916587195001

Karapetyan, E. T., \& Kvasovskyi, O. R. (2013). Analiz rinku žitlovoï neruhomosti v Ukraïni [Analysis of the housing market in Ukraine]. Naukovij visnik: Finansi, banki, investiciï, 2, 125134.

Kovtyn, M. V. (2014). Stanovlennja ta rozvitok rinku žitla Ukraïni v umovah rinkovih peretvoren [The formation and development of the housing market in Ukraine in terms of market reforms]. Naukovij visnik Užgorodskogo universitetu, 42, 282-286.

Myhalevych, V. V., \& Kyrylenko, M. O. (2016). Tendenciï rozvitku malogabaritnogo žitla (sučasnij svitovij dosvid) [Trends compact housing (modern world experience)]. Problemi rozvitku miskogo seredovisa, 1(15), 52-59.

Omelchyk, V. O. (2010). Adekvatnist žitlovogo budivnictva v Ukraïni suspilnomu popitu [Adequate of housing construction in Ukraine to public demand]. Investiciï: praktika ta dosvid, 21, 23-27.

Oyewole, M. O. (2010). Housing development finance through cooperative societies. International Journal of Housing Markets and Analysis, 3(3), 245-255. https://doi.org/10.1108/17538271011063906 
State Statistics Service of Ukraine. (2017). Retrieved from http://ukrstat.gov.ua/

Sych, O. S. (2015). Problemi ta perspektivi rozvitku rinku žitlovogo budivnictva v Ukraïni [Problems and prospects of the housing market in Ukraine]. Visnik NTU «HPI», 54(1163), $59-62$.

Thalmann, P. (1999). Identifying households which need housing assistance. Urban Studies, 36(11), 1933-1947. https://doi.org/10.1080/0042098992683

The statistical office of the European Union - Eurostat. (2017). Retrieved from http://ec.europa.eu/ eurostat/statistics-explained/index.php/File:Average_size_of_dwelling_by_tenure_status,_2012.png Zapototskyy, S., Zapototska, V., \& Gorin, I. (2014). Tendenciï ta perspektivi žitlovogo budivnictva v Ukraini [Trends and prospects of houses construction in Ukraine]. Geografija, 1(62), 45-49.

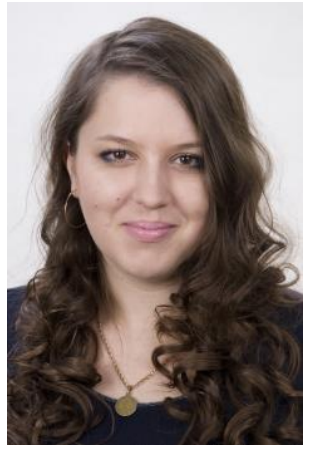

\section{AUTHORS' SHORT BIOGRAPHIES}

Natalya Bibik received a $\mathrm{PhD}$ degree in economics from Kharkiv National Academy of Municipal Economy of the Ministry of Education and Science of Ukraine in 2010. The thesis was devoted to solving a crucial scientific and practical issue - the improvement of organizational-economic mechanism of regional development management (by the example of Kharkiv Region).

Dr. Bibik is currently an Associate Professor with the Faculty of Enterprise Economics of O. M. Beketov National University of Urban Economy in Kharkiv, Ukraine. Her main research is related to real estate, construction industry development, regional development, sustainable development. She is the author and co-author of more than 40 scientific publications.

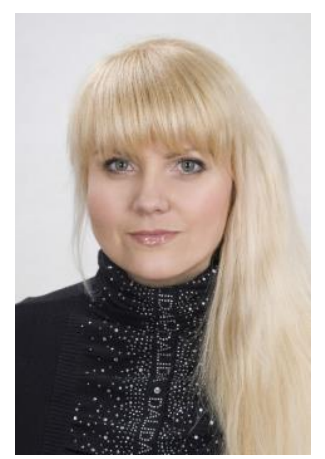

Natalia Dril Assistant of Professor at the Department of Enterprise Economics, Business Administration and Regional Development of O. M. Beketov National University of Urban Economy in Kharkiv. Her research interests include innovation and investment activities of construction companies, corporate social responsibility, enterprise strategy, enterprise risk, financial literacy. 